\title{
The serum 25-hydroxyvitamin D levels and hip fracture risk: a meta-analysis of prospective cohort studies
}

\author{
Qing-Bo Lv ${ }^{1}$, Xiang Gao ${ }^{1}$, Xiang Liu ${ }^{1}$, Zhen-Xuan Shao ${ }^{1}$, Qian-Hui X ${ }^{1}{ }^{1}$, Li Tang ${ }^{1}$, \\ Yong-Long $\mathrm{Chi}^{1}$ and $\mathrm{Ai}-\mathrm{Min} \mathrm{Wu}^{1}$ \\ ${ }^{1}$ Department of Orthopedics, Bone Research Institute, The Second Affiliated Hospital and Yuying Children's Hospital of \\ Wenzhou Medical University, Second Medical School of Wenzhou Medical University, Wenzhou, Zhejiang, China
}

Correspondence to: Ai-Min Wu, email: aiminwu2005@163.com

Keywords: serum 25-hydroxyvitamin D, hip fracture, meta-analysis, dose-response

Received: December 14.2016 Accepted: February 13, 2017

Published: March 17, 2017

Copyright: Lv et al. This is an open-access article distributed under the terms of the Creative Commons Attribution License (CC-BY), which permits unrestricted use, distribution, and reproduction in any medium, provided the original author and source are credited.

\section{ABSTRACT}

Hip fracture has increasingly become a social and economic burden. The relationship between serum 25-hydroxyvitamin D levels and the risk of hip fracture reported by previous studies remains controversial. We searched Pubmed and Embase to identify studies reporting the relationship between serum 25-hydroxyvitamin D levels and risk of hip fracture. Fifteen prospective cohort studies with a total of 51239 participants and 3386 hip fracture cases were included. By pooling the Relative Risk of the lowest vs. the highest categories indicated that lower levels of serum 25-hydroxyvitamin D were more likely to be a risk factor for hip fracture with adjusted Relative Risk (95\%Confidence Interval) of $1.58(1.41,1.77)$. Subgroup meta-analysis examining the stability of the primary results achieved the same results. A dose-response meta-analysis showed that the risk of hip fracture was a descending curve below the line of $R=1$. The descending trend was obvious when serum 25-hydroxyvitamin $D$ levels were less than $60 \mathrm{nmol} / \mathrm{L}$ and was flat when serum 25-hydroxyvitamin D levels were more than $60 \mathrm{nmol} / \mathrm{L}$. We found that individuals with low levels of serum 25-hydroxyvitamin D have an increased risk of hip fracture, and this effect was evident when the serum 25-hydroxyvitamin $D$ levels were less than $60 \mathrm{nmol} / \mathrm{L}$.

\section{INTRODUCTION}

Hip fracture as a serious consequence of osteoporosis is becoming an important health problem, and an increasing social and economic burden [1-3], and hip fractures are expected to receive more attention over the coming years [4-6]. Cenzer et al [7] reported that about $27 \%$ hip fracture patients dead during the 1-year follow up. Multiple factors have been shown to be associated with the risk of hip fractures [8-11]. It is widely recognized that vitamin D plays an important role in skeletal health [12$15]$.

Serum 25-hydroxyvitamin D $[25(\mathrm{OH}) \mathrm{D}]$ is widely recognized as the indicator of vitamin $\mathrm{D}$ [16]. Steingrimsdottir et al [17] found that serum 25(OH)D $<$ $30 \mathrm{nmol}$ had higher risk of hip fractures than the $25(\mathrm{OH})$ D with 50-75 nmol/L (Hazard ratios: 2.24 (95\% CI 1.63, 3.09)). Similar result was found in study of Looker et al
[18]. However, in study of Barbour et al [19], they found no evidence of an association between 25(OH)D and any non-spine fractures, and similar result was found in studies of Cummings et al [20] (25(OH)D less than $47.5 \mathrm{nmol} / \mathrm{L}$ (19 ng/ml) with RR: $1.2(0.7-1.9))$, Chan et al [21] with (RR: 0.63 (0.15-2.62)), and de Boer et al [22] with (RR: $1.34(0.97-1.84))$.

Therefore, the effect of serum 25(OH)D concentrations on hip fracture remains uncertain, and we conducted this meta-analysis for the purpose of determining the association between serum 25(OH)D concentrations and the risk of hip fracture. Moreover, which is optimal serum $25(\mathrm{OH}) \mathrm{D}$ concentration? And will the sex, age, geographic region or study design (cohort or nested case-cohort) influence the outcomes? Doseresponse and subgroup analysis (sex, age, geographic region or study design) were performed to help us understand more about serum 25(OH)D levels and their relationship to the risk of hip fracture. 


\section{RESULTS}

\section{Literature search}

The detailed steps of our literature selection are shown in Figure 1. A total of 399 potential records were identified from the databases, including 88 duplicate articles, 311 articles leaved after duplications deleted; then, 222 papers were excluded by screening the abstracts, and 89 full articles were retrieved. There were 74 articles excluded, including 11 review articles, 12 studies that examined other types of fractures and $25(\mathrm{OH}) \mathrm{D}, 17$ non-prospective cohort studies, 2 meeting articles, 17 articles about other factors affecting the bone health (not including fracture) and $25(\mathrm{OH}) \mathrm{D}$, and 15 studies research the prevalence of vitamin D insufficiency in patient of any kind of fracture (didn't have hip fracture data). Overall, Fifteen prospective cohort studies [17-31] that referred to the relationship between serum 25(OH)D levels and hip fractures were included.

\section{Study characteristics}

The characteristics of the included studies are presented in Table 1. A total of 51239 participants were included in our meta-analysis, of whom 3386 had a hip fracture. Fourteen of the fifteen studies were conducted during the period from 2007 to 2016 , and there was only one article that was conducted in 1998. Of these fifteen studies, there were eleven cohort studies and four nested case-cohort studies; five of the studies were conducted in Europe and eight were conducted in the United States, one was conducted in the HongKong and one was conducted in the New Zealand. These studies met the criteria for high quality ( 7 to 9 stars). Most studies provided risk estimates that were adjusted for age (14 studies), BMI (10 studies), gender (8 studies), drinking (7 studies), smoking (10 studies), physical activity (7 studies) and weight (4 studies) (Table 1).

\section{Serum 25(OH)D levels and hip fracture risk}

There were thirteen studies that referred to the relationship between serum $25(\mathrm{OH}) \mathrm{D}$ levels and the risk

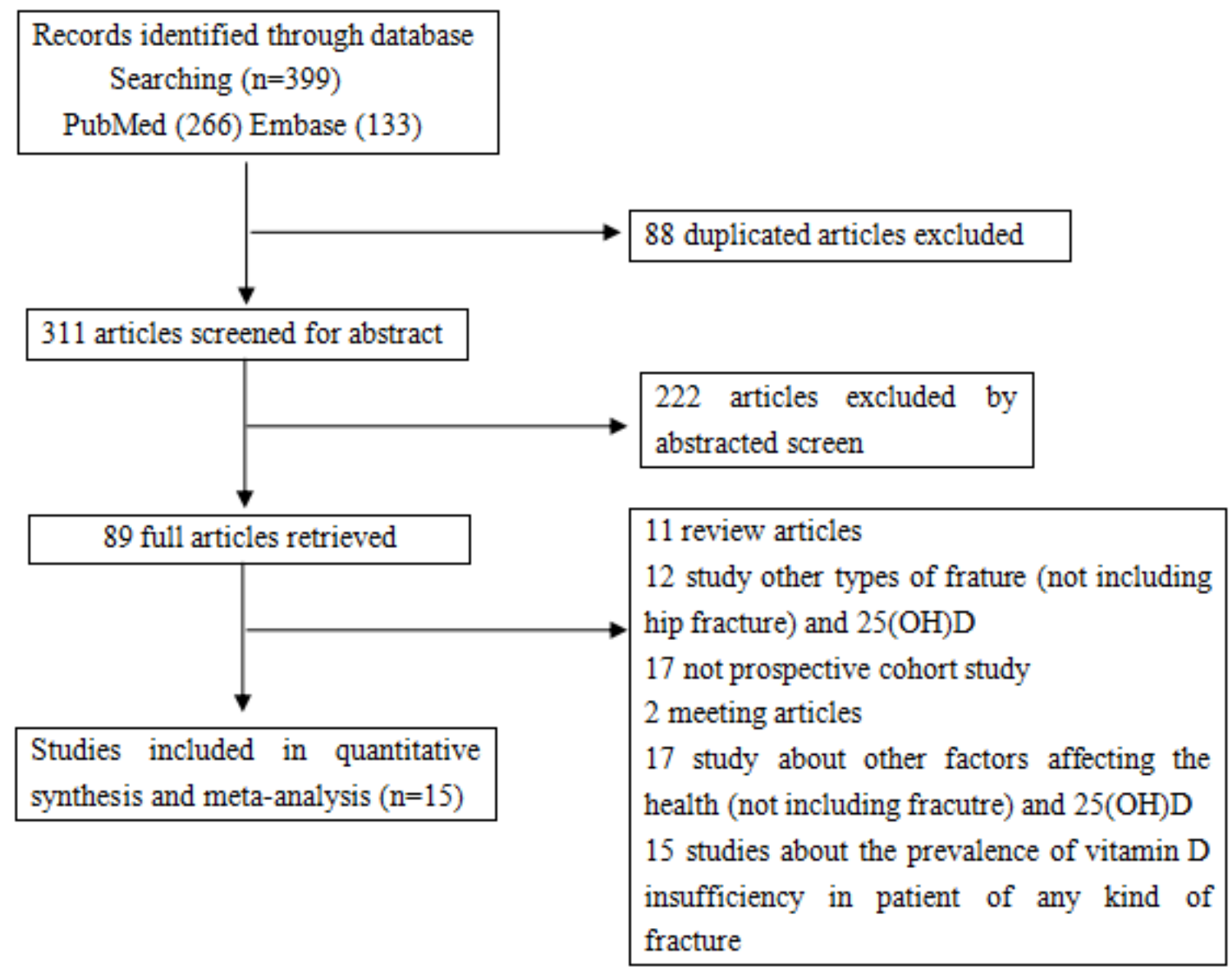

Figure 1: The selection of literature for included studies. 
Table 1: Characteristics of Prospective Studies on Serum 25-Hydroxyvitamin D and Hip Fracture

\begin{tabular}{|c|c|c|c|c|c|c|c|c|c|}
\hline Source & $\begin{array}{l}\text { Study } \\
\text { Type }\end{array}$ & $\begin{array}{c}\text { No. of } \\
\text { participants }\end{array}$ & $\begin{array}{l}\text { Location/ } \\
\text { Period }\end{array}$ & Gender & $\begin{array}{c}\text { Age } \\
\text { (years) }\end{array}$ & $\begin{array}{l}\text { No. of } \\
\text { casesa }\end{array}$ & $\begin{array}{l}\text { Measure/Range of } \\
\text { concentrations }\end{array}$ & $\begin{array}{c}\text { Study } \\
\text { Qualityb }\end{array}$ & $\begin{array}{l}\text { Adjustment for } \\
\text { Covariatesc }\end{array}$ \\
\hline $\begin{array}{l}\text { Steingrimsdottir } \\
\text { et al } \\
2014\end{array}$ & $\begin{array}{l}\text { Cohort } \\
\text { study }\end{array}$ & 5461 & $\begin{array}{l}\text { Iceland } \\
\text { 2002-2009 }\end{array}$ & $\begin{array}{l}\mathrm{F}: 3125 \\
\mathrm{M}: 2346\end{array}$ & $66-96$ & $261 \mathrm{HF}$ & $\begin{array}{l}\mathrm{Q} 1<30 \mathrm{nmol} / \mathrm{L} \\
30 \mathrm{nmol} / \mathrm{L} \leq \mathrm{Q} 2<50 \\
\mathrm{nmol} / \mathrm{L} \\
50 \mathrm{nmol} / \mathrm{L} \leq \mathrm{Q} 3<75 \\
\mathrm{nmol} / \mathrm{L} \\
\mathrm{Q} 4 \geq 75 \mathrm{nmol} / \mathrm{L} \\
\text { (Immune based) }\end{array}$ & 9 & $\begin{array}{l}\text { Age, sex, body mass } \\
\text { index, height, smoking, } \\
\text { alcohol intake and } \\
\text { season,physical activity. }\end{array}$ \\
\hline $\begin{array}{l}\text { Khaw et al } \\
2014\end{array}$ & $\begin{array}{l}\text { Cohort } \\
\text { study }\end{array}$ & 14641 & $\begin{array}{l}\text { United } \\
\text { Kingdom } \\
1997-2012\end{array}$ & $\begin{array}{l}\mathrm{F}: 8155 \\
\mathrm{M}: 6486\end{array}$ & $42-82$ & $198 \mathrm{HF}$ & $\begin{array}{l}\mathrm{Q} 1<30 \mathrm{nmol} / \mathrm{L} \\
30 \mathrm{nmol} / \mathrm{L} \leq \mathrm{Q} 2<50 \\
\mathrm{nmol} / \mathrm{L} \\
50 \mathrm{nmol} / \mathrm{L} \leq \mathrm{Q} 3<70 \\
\mathrm{nmol} / \mathrm{L} \\
70 \mathrm{nmol} / \mathrm{L} \leq \mathrm{Q} 4<90 \\
\mathrm{nmol} / \mathrm{L} \\
\mathrm{Q} 5 \geq 90 \mathrm{nmol} / \mathrm{L} \\
\text { (Chromatography } \\
\text { based) }\end{array}$ & 9 & $\begin{array}{l}\text { Age, sex, month, } \\
\text { BMI, physical activity, } \\
\text { smoking, alcohol, vitamin } \\
\text { C, diabetes, history of } \\
\text { cardiovascular disease, } \\
\text { history of cancer, social } \\
\text { class, and education . }\end{array}$ \\
\hline $\begin{array}{l}\text { Barbour et al } \\
2012\end{array}$ & $\begin{array}{l}\text { Cohort } \\
\text { study }\end{array}$ & 2640 & $\begin{array}{l}\text { United } \\
\text { States } \\
1997-2009\end{array}$ & $\begin{array}{l}\mathrm{F}: 1291 \\
\mathrm{M}: 1349\end{array}$ & $70-79$ & $84 \mathrm{HF}$ & $\begin{array}{l}\mathrm{Q} 1 \leq 44.45 \mathrm{nmol} / \mathrm{L} \\
44.48 \mathrm{nmol} / \\
\mathrm{L} \leq \mathrm{Q} 2 \leq 60.9 \mathrm{nmol} / \mathrm{L} \\
60.93 \mathrm{nmol} / \\
\mathrm{L} \leq \mathrm{Q} 3 \leq 79.85 \mathrm{nmol} / \mathrm{L} \\
\mathrm{Q} 4>79.85 \mathrm{nmol} / \mathrm{L} \\
\text { (Immune based) }\end{array}$ & 9 & $\begin{array}{l}\text { Age, gender, race, } \\
\text { education level, season } \\
\text { of blood draw, BMI, } \\
\text { current drinking, fracture } \\
\text { after age } 45 \text { and clinical } \\
\text { comorbidity index. }\end{array}$ \\
\hline $\begin{array}{l}\text { Robinson- } \\
\text { Cohen et al } \\
2011\end{array}$ & $\begin{array}{l}\text { Cohort } \\
\text { study }\end{array}$ & 2294 & $\begin{array}{l}\text { United } \\
\text { States } \\
\text { 1989-2009 }\end{array}$ & $\begin{array}{l}\mathrm{F}: 1600 \\
\mathrm{M}: 694\end{array}$ & $\geq 65$ & $244 \mathrm{HF}$ & $\begin{array}{l}\mathrm{Q} 1<37.5 \mathrm{nmol} / \mathrm{L} \\
\mathrm{Q} 2 \geq 37.5 \mathrm{nmol} / \mathrm{L} \\
\text { (Chromatography } \\
\text { based) }\end{array}$ & 8 & $\begin{array}{l}\text { Age, race, sex, clinic } \\
\text { site, a season, education, } \\
\text { smoking status (never } \\
\text { smoker, former smoker, or } \\
\text { current, smoker), alcohol } \\
\text { use (any vs. none), } \\
\text { diabetes status (normal, } \\
\text { impaired fasting glucose, } \\
\text { or diabetes), body mass } \\
\text { index, self-reported health } \\
\text { status, physical activity } \\
\text { level, oral steroid use, } \\
\text { estrogen use, thiamine } \\
\text { and loop diuretic use, } \\
\text { serum cystatin C level, } \\
\text { and calcium supplement } \\
\text { use. }\end{array}$ \\
\hline $\begin{array}{l}\text { Looker et al } \\
2008\end{array}$ & $\begin{array}{l}\text { Cohort } \\
\text { study }\end{array}$ & 1917 & $\begin{array}{l}\text { United } \\
\text { States } \\
1991-2000\end{array}$ & $\begin{array}{l}\mathrm{F}: 986 \\
\mathrm{M}: 931\end{array}$ & $\geq 65$ & $156 \mathrm{HF}$ & $\begin{array}{l}\text { 0nmol/L } \leq \mathrm{Q} 1 \leq 42.9 \\
\mathrm{nmol} / \mathrm{L} \\
43 \mathrm{nmol} / \mathrm{L} \leq \mathrm{Q} 2 \leq 61 \\
\mathrm{nmol} / \mathrm{L} \\
61.1 \mathrm{nmol} / \mathrm{L} \leq \mathrm{Q} 3<82.5 \\
\mathrm{nmol} / \mathrm{L} \\
\mathrm{Q} 4 \geq 82.5 \mathrm{nmol} / \mathrm{L} \\
\text { (Immune based) }\end{array}$ & 9 & $\begin{array}{l}\text { Age, sex, femoral neck } \\
\text { BMD, BMI, previous } \\
\text { fracture, dietary calcium, } \\
\text { kilocalories, and weight } \\
\text { loss from maximum. }\end{array}$ \\
\hline $\begin{array}{l}\text { Holvik et al } \\
2013\end{array}$ & $\begin{array}{l}\text { Case- } \\
\text { cohort } \\
\text { study }\end{array}$ & 2526 & $\begin{array}{l}\text { Norway } \\
1994-2001\end{array}$ & $\begin{array}{l}\mathrm{F}: 1819 \\
\mathrm{M}: 707\end{array}$ & $65-79$ & $1175 \mathrm{HF}$ & $\begin{array}{l}4.5 \mathrm{nmol} / \mathrm{L} \leq \mathrm{Q} 1 \leq 42.1 \\
\mathrm{nmol} / \mathrm{L} \\
42.2 \mathrm{nmol} / \mathrm{L} \leq \mathrm{Q} 2<53.5 \\
\mathrm{nmol} / \mathrm{L} \\
53.5 \mathrm{nmol} / \\
\mathrm{L} \leq \mathrm{Q} 3 \leq 67.8 \mathrm{nmol} / \mathrm{L} \\
67.9 \mathrm{nmol} / \\
\mathrm{L} \leq \mathrm{Q} 4 \leq 250.0 \mathrm{nmol} / \mathrm{L} \\
\text { (Mass spectrometry) }\end{array}$ & 9 & $\begin{array}{l}\text { Age, gender, study center, } \\
\text { BMI, and month of blood } \\
\text { sample. }\end{array}$ \\
\hline $\begin{array}{l}\text { Cauley et al } \\
2010\end{array}$ & $\begin{array}{l}\text { Case- } \\
\text { cohort } \\
\text { study }\end{array}$ & 1665 & $\begin{array}{l}\text { United } \\
\text { States } \\
2000-2002\end{array}$ & M:1665 & $\geq 65$ & $81 \mathrm{HF}$ & $\begin{array}{l}7.83 \mathrm{nmol} / \mathrm{L} \leq \mathrm{Q} 1<47.5 \\
\mathrm{nmol} / \mathrm{L} \\
47.5 \mathrm{nmol} / \\
\mathrm{L} \leq \mathrm{Q} 2<62.75 \mathrm{nmol} / \mathrm{L} \\
62.75 \mathrm{nmol} / \\
\mathrm{L} \leq \mathrm{Q} 3<74.75 \mathrm{nmol} / \mathrm{L} \\
\mathrm{Q} 4 \geq 74.75 \mathrm{nmol} / \mathrm{L} \\
\text { (Chromatography } \\
\text { based) }\end{array}$ & 8 & $\begin{array}{l}\text { Age, race, clinic, season } \\
\text { of blood draw, physical } \\
\text { activity, weight, and } \\
\text { height. }\end{array}$ \\
\hline
\end{tabular}




\begin{tabular}{|c|c|c|c|c|c|c|c|c|c|}
\hline $\begin{array}{l}\text { Cauley et al } \\
2008\end{array}$ & $\begin{array}{l}\text { Case- } \\
\text { cohort } \\
\text { study }\end{array}$ & 800 & $\begin{array}{l}\text { United } \\
\text { States } \\
1994-2004\end{array}$ & $F: 800$ & $50-79$ & $400 \mathrm{HF}$ & $\begin{array}{l}9.23 \mathrm{nmol} / \mathrm{L} \leq \mathrm{Q} 1<47.6 \\
\mathrm{nmol} / \mathrm{L} \\
47.6 \mathrm{nmol} / \mathrm{L} \leq \mathrm{Q} 2<60.2 \\
\mathrm{nmol} / \mathrm{L} \\
60.2 \mathrm{nmol} / \\
\mathrm{L} \leq \mathrm{Q} 3<70.7 \mathrm{nmol} / \mathrm{L} \\
70.7 \mathrm{nmol} / \\
\mathrm{L} \leq \mathrm{Q} 4<121.5 \mathrm{nmol} / \mathrm{L} \\
\text { (Immune based) } \\
\end{array}$ & 9 & $\begin{array}{l}\text { Age, body mass index, } \\
\text { parental history of hip } \\
\text { fracture, history of } \\
\text { fracture, smoking, alcohol } \\
\text { use, and total calcium } \\
\text { intake, oral corticosteroid } \\
\text { use and geographic } \\
\text { region. }\end{array}$ \\
\hline $\begin{array}{l}\text { Cummings et al } \\
1998\end{array}$ & $\begin{array}{l}\text { Case- } \\
\text { cohort } \\
\text { study }\end{array}$ & 476 & $\begin{array}{l}\text { United } \\
\text { States } \\
1986-1988\end{array}$ & $F: 476$ & $\geq 65$ & $133 \mathrm{HF}$ & $\begin{array}{l}\mathrm{Q} 1<47.5 \mathrm{nmol} / \mathrm{L} \\
\mathrm{Q} 2 \geq 47.5 \mathrm{nmol} / \mathrm{L} \\
\text { (Immune based) }\end{array}$ & 8 & Age and weight \\
\hline $\begin{array}{l}\text { Bolland et al } \\
2010\end{array}$ & $\begin{array}{l}\text { Cohort } \\
\text { study }\end{array}$ & 1471 & $\begin{array}{l}\text { New } \\
\text { Zealand } \\
\text { 1998-2003 }\end{array}$ & $F: 1471$ & $>50$ & $22 \mathrm{HF}$ & $\begin{array}{l}\mathrm{Q} 1<50 \mathrm{nmol} / \mathrm{L} \\
\mathrm{Q} 2 \geq 50 \mathrm{nmol} / \mathrm{L} \\
\text { (Immune based) }\end{array}$ & 9 & $\begin{array}{l}\text { Treatment allocation } \\
\text { (calcium or placebo) } \\
\text { and baseline age, body } \\
\text { weight, and smoking } \\
\text { status. }\end{array}$ \\
\hline $\begin{array}{l}\text { Melhus et al } \\
2010\end{array}$ & $\begin{array}{l}\text { Cohort } \\
\text { study }\end{array}$ & 1194 & Sweden & M:1194 & $>50$ & $73 \mathrm{HF}$ & $\begin{array}{l}\mathrm{Q} 1<50 \mathrm{nmol} / \mathrm{L} \\
\mathrm{Q} 2 \geq 50 \mathrm{nmol} / \mathrm{L} \\
\text { (Chromatography } \\
\text { based) }\end{array}$ & 9 & $\begin{array}{l}\text { Weight, height, age, } \\
\text { cystatin C, calcium } \\
\text { intake, season, physical } \\
\text { activity, smoking, } \\
\text { diabetes mellitus, other } \\
\text { endocrine disease, } \\
\text { hematological diseases, } \\
\text { dermatoses, infectious } \\
\text { disease, musculoskeletal } \\
\text { disease, psychiatric } \\
\text { disease, neurological } \\
\text { disease, respiratory } \\
\text { disease, kidney or urinary } \\
\text { disease, gastrointestinal } \\
\text { disease. } \\
\end{array}$ \\
\hline Chan et al 2011 & $\begin{array}{l}\text { Cohort } \\
\text { study }\end{array}$ & 712 & HongKong & M:712 & $\geq 65$ & $24 \mathrm{HF}$ & $\begin{array}{l}\mathrm{Q} 1 \leq 63 \mathrm{nmol} / \mathrm{L} \\
63 \mathrm{nmol} / \mathrm{L}<\mathrm{Q} 2 \leq 76 \\
\mathrm{nmol} / \mathrm{L} \\
76 \mathrm{nmol} / \mathrm{L}<\mathrm{Q} 3 \leq 91 \\
\mathrm{nmol} / \mathrm{L} \\
\mathrm{Q} 4>91 \mathrm{nmol} / \mathrm{L} \\
\text { (Immune based) }\end{array}$ & 9 & $\begin{array}{l}\text { Age, BMI, education, } \\
\text { PASE, DQI, smoking } \\
\text { status, and alcohol use }\end{array}$ \\
\hline $\begin{array}{l}\text { Buchebner et al } \\
2014\end{array}$ & $\begin{array}{l}\text { Cohort } \\
\text { study }\end{array}$ & 1044 & Sweden & $F: 1044$ & $\geq 75$ & $130 \mathrm{HF}$ & $\begin{array}{l}\mathrm{Q} 1<50 \mathrm{nmol} / \mathrm{L} \\
50 \mathrm{nmol} / \mathrm{L} \leq \mathrm{Q} 2 \leq 75 \\
\mathrm{nmol} / \mathrm{L} \\
\mathrm{Q} 3>75 \mathrm{nmol} / \mathrm{L} \\
\text { (Chromatography } \\
\text { based) }\end{array}$ & 7 & $\begin{array}{l}\text { smoking, bisphosphonate } \\
\text { use, and physical activity } \\
\text { level }\end{array}$ \\
\hline $\begin{array}{l}\text { de Boer et al } \\
2012\end{array}$ & $\begin{array}{l}\text { Cohort } \\
\text { study }\end{array}$ & 1621 & $\begin{array}{l}\text { United } \\
\text { States } \\
1992-2006\end{array}$ & $\begin{array}{l}\text { F:1130 } \\
\text { M:491 }\end{array}$ & $\geq 65$ & $137 \mathrm{HF}$ & $\begin{array}{l}\mathrm{Q} 1<50 \mathrm{nmol} / \mathrm{L} \\
\mathrm{Q} 2 \geq 50 \mathrm{nmol} / \mathrm{L}\end{array}$ & 9 & $\begin{array}{l}\text { Age, sex, clinical site, } \\
\text { smoking, body mass } \\
\text { index, and physical } \\
\text { activity. }\end{array}$ \\
\hline $\begin{array}{l}\text { Takiar et al } \\
2015\end{array}$ & $\begin{array}{l}\text { Cohort } \\
\text { study }\end{array}$ & 12781 & $\begin{array}{l}\text { United } \\
\text { States } \\
1990-1992\end{array}$ & $\begin{array}{l}\text { F:7196 } \\
\text { M:5585 }\end{array}$ & $\begin{array}{l}\text { Mean } \\
57\end{array}$ & $267 \mathrm{HF}$ & $\begin{array}{l}\mathrm{Q} 1<50 \mathrm{nmol} / \mathrm{L} \\
\mathrm{Q} 2 \geq 50 \mathrm{nmol} / \mathrm{L}\end{array}$ & 9 & $\begin{array}{l}\text { Age, sex, and race/cente, } \\
\text { potentially confounding } \\
\text { variables of education, } \\
\text { annual household income, } \\
\text { physical activity, smoking } \\
\text { status, alcohol drinking } \\
\text { status, body mass index, } \\
\text { waist-to-hip ratio, } \\
\text { diabetes, systolic and } \\
\text { diastolic blood pressure, } \\
\text { use of hypertension } \\
\text { medication, total and } \\
\text { HDL cholesterol, } \\
\text { estimated glomerular } \\
\text { filtration rate, thiazide } \\
\text { diuretic usage, and } \\
\text { hormone replacement } \\
\text { therapy, calcium, } \\
\text { phosphate, and PTH } \\
\text { levels. }\end{array}$ \\
\hline
\end{tabular}

a: HF: Hip fracture.

b: Study quality was judged based on the Newcastle-Ottawa Scale (range, 1-9 stars).

c: BMI: body mass index; BMD: Bone mineral density. 
of hip fracture. The results of the meta-analysis are shown in Figure 2. The pooled adjusted RRs of hip fracture for the lowest versus highest categories of serum 25(OH)D concentrations were $1.58(1.41,1.77)$ without significant heterogeneity $\left(\mathrm{I}^{2}=16.8 \%, P=0.265\right)$, the meta-regression of year, age, follow-up term, study-type, gender and location showed no heterogeneity was found (all of the $P$ $>0.10$, Supplementary Figure S1). Additionally, there was no indication of significant publication bias via Egger's test $(P=0.427)$.

\section{Subgroup meta-analysis}

The results of the subgroup meta-analysis are shown in the Table 2. We found that low levels of serum $25(\mathrm{OH})$ $\mathrm{D}$ increased the risk of hip fracture when it was defined by gender (male: 1.86 (1.36 to 2.56); female: 1.45 (1.20 to $1.70)$ ), age ( $\geq 65$ years: 1.61 ( 1.41 to 1.84$)$; $\geq 42$ years: 1.49 (1.19 to 1.85$)$ ), location (Europe: 1.64 (1.37 to 1.97$)$; USA: $1.56(1.34$ to 1.80$)$ ), study type (cohort: $1.67(1.45$ to 1.93); nested case-cohort: 1.42 (1.17 to 1.72$)$ ), and duration of follow-up ( $<7$ years: 1.89 (1.52 to 2.35 ); $\geq 7$ years: 1.48 (1.29 to 1.69$))$.

\section{Dose-response meta-analysis}

Four studies $[17,21,24,26]$ of serum $25(\mathrm{OH})$ $\mathrm{D}$ concentration and risk of hip fracture met the doseresponse meta-analysis criteria. The results of generalized least-squares regression for serum 25(OH)D levels and the adj.RR of hip fracture are shown in the Figure 3 as a descending curve below the line of $\mathrm{RR}=1$. The descending trend was obvious when the serum $25(\mathrm{OH}) \mathrm{D}$ level was below $60 \mathrm{nmol} / \mathrm{L}$ and flattened when the serum $25(\mathrm{OH}) \mathrm{D}$ level was higher than $60 \mathrm{nmol} / \mathrm{L}$; there was no significant linear association between the serum $25(\mathrm{OH})$ $\mathrm{D}$ levels and the risk of hip fracture $(P=0.110$ for nonlinearity, Figure 3).

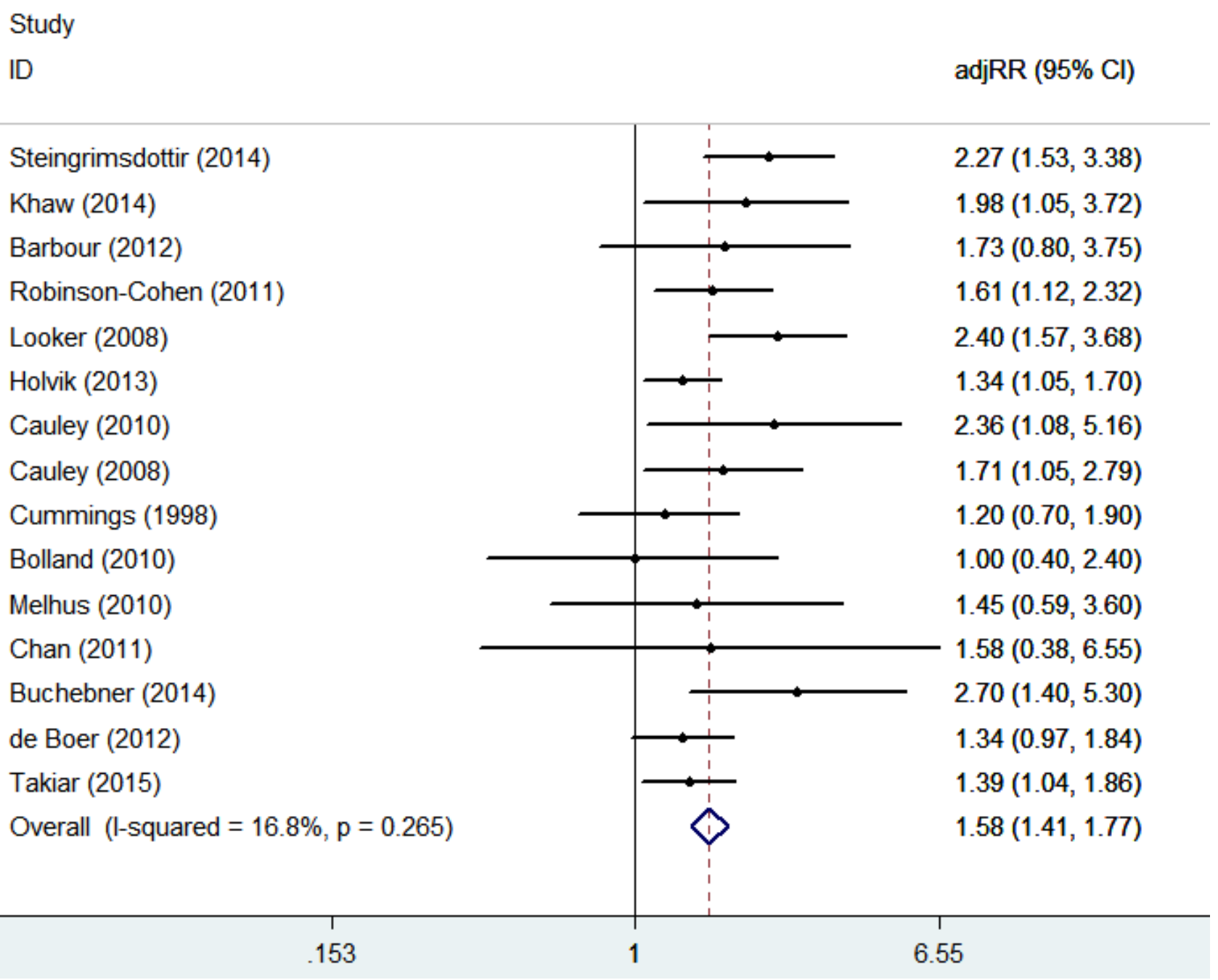

Figure 2: Adjusted Relative Risks of hip fracture for the lowest vs. highest categories of serum 25(OH)D levels. 
Table 2: Subgroup analyses for 25(OH)D and hip fracture

\begin{tabular}{|c|c|c|c|c|c|}
\hline & No. of reports & Relative Risk (95CI\%) & $P$ for heterogeneity & $I^{2}$ & $P$ for test \\
\hline \multicolumn{6}{|l|}{ Sex } \\
\hline Male & 5 & $1.86(1.36$ to 2.56$)$ & 0.695 & 0.0 & 0.000 \\
\hline Female & 6 & $1.45(1.20$ to 1.75$)$ & 0.181 & 34.1 & 0.000 \\
\hline \multicolumn{6}{|l|}{ Age } \\
\hline$\geq 65$ years & 10 & $1.61(1.41$ to 1.84$)$ & 0.110 & 37.3 & 0.000 \\
\hline$\geq 42$ years & 5 & $1.49(1.19$ to 1.85$)$ & 0.722 & 0 & 0.000 \\
\hline \multicolumn{6}{|l|}{ Location } \\
\hline Europe & 5 & $1.64(1.37$ to 1.97$)$ & 0.096 & 49.2 & 0.000 \\
\hline USA & 8 & $1.56(1.34$ to 1.80$)$ & 0.355 & 9.7 & 0.000 \\
\hline \multicolumn{6}{|l|}{ Study type } \\
\hline Cohort & 11 & $1.67(1.45$ to 1.93$)$ & 0.277 & 17.5 & 0.000 \\
\hline Case-cohort & 4 & $1.42(1.17$ to 1.72$)$ & 0.418 & 0.0 & 0.000 \\
\hline \multicolumn{6}{|c|}{ Duration of follow-up } \\
\hline$<7$ years & 7 & $1.89(1.52$ to 2.35$)$ & 0.271 & 20.8 & 0.000 \\
\hline$\geq 7$ years & 6 & $1.48(1.29$ to 1.69$)$ & 0.575 & 0.0 & 0.000 \\
\hline
\end{tabular}

\section{DISCUSSION}

Hip fracture has been worldwide burden [32] and the association of low levels of serum $25(\mathrm{OH}) \mathrm{D}$ and risk of fracture among older adults was unclear [18, $19,23,25,27,33]$. A previous meta-analysis based on randomized controlled trials and observational studies [34] showed that neither higher nor lower doses of vitamin D supplementation led to an increased risk of hip fracture; it found that the serum $25(\mathrm{OH}) \mathrm{D}$ levels in the 17 identified case-control studies were 33\% lower in the case groups compared to the control groups [34].

We found that the adjusted relative risk (adj.RR) of low levels of $25(\mathrm{OH}) \mathrm{D}$ has a statistically significant $58 \%$ increased risk of hip fracture. All of the subgroup metaanalyses of different genders, age ranges, locations, study

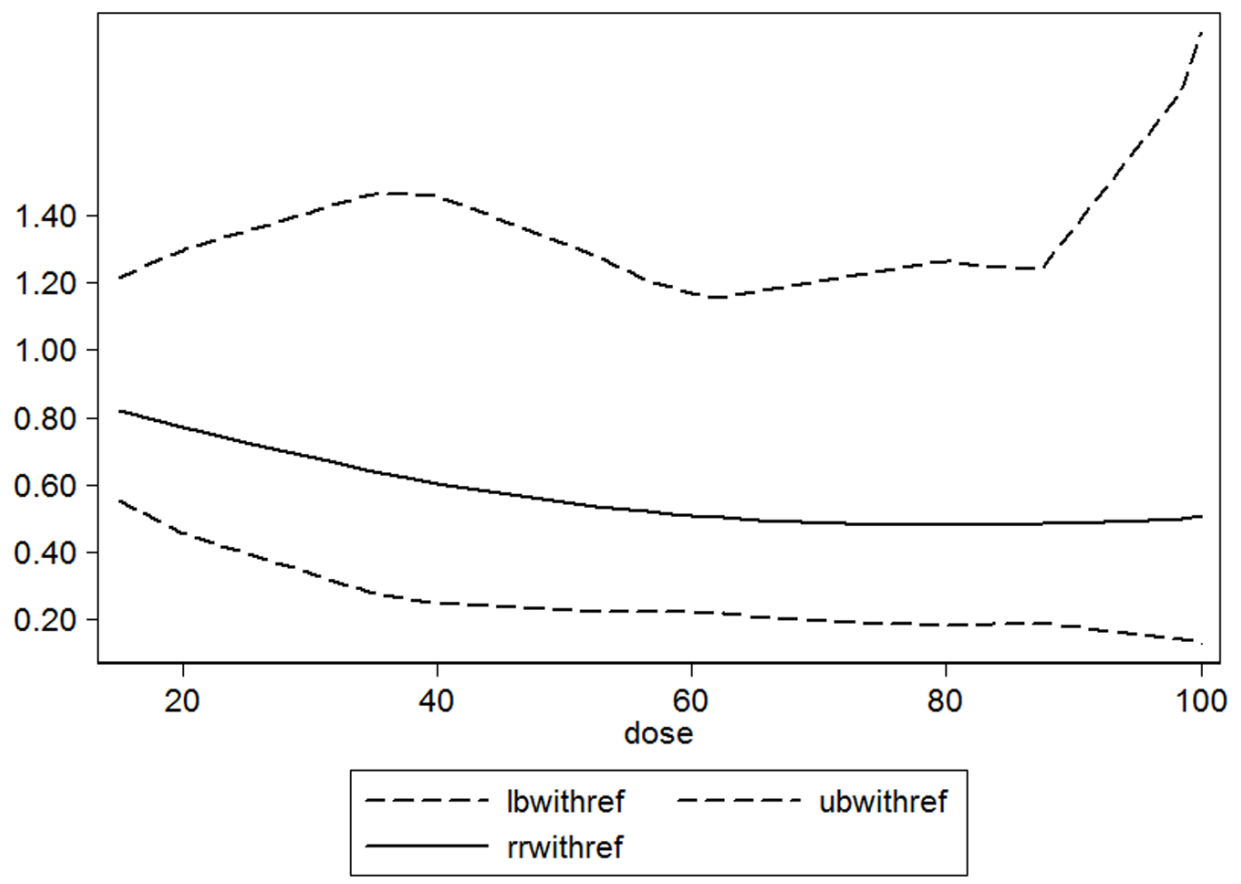

Figure 3: Dose-response relationship between serum 25(OH)D and relative risk of hip fracture. Solid line represents adjusted relative risk and dotted lines represent the $95 \%$ confidence intervals for the fitted trend. Adj.RR of hip fracture is a descending curve below the line of $\mathrm{RR}=1$. The descending trend was obvious when serum $25(\mathrm{OH}) \mathrm{D}$ level was less than $60 \mathrm{nmol} / \mathrm{L}$, and flat when serum $25(\mathrm{OH}) \mathrm{D}$ was higher than $60 \mathrm{nmol} / \mathrm{L}$; there was no significant linear association between the serum 25(OH)D levels and the risk of hip fracture $(P=0.110$ for non-linearity). 
types, and durations of follow up supported the result that lower serum 25(OH)D levels significantly increased the risk of hip fracture.

Serum $25(\mathrm{OH}) \mathrm{D}$ is the indicator of vitamin D. Therefore, low levels of serum $25(\mathrm{OH}) \mathrm{D}$ may be associated with bone loss, lower bone mineral density (BMD) and higher bone turnover [35], which may cause a high risk of fracture. Some other indirect factors may increase the risk of hip fracture, including muscle strength, balance and intake of nutrients; the deficiency of vitamin $\mathrm{D}$ may decrease muscle strength and balance, and may also be combined with deficiencies of other nutrient [3638]. It was also reported that vitamin $D$ deficiency may increase the risk of falls, which then may increase hip fracture risk $[39,40]$. Finally, low levels of serum $25(\mathrm{OH})$ $\mathrm{D}$ may be connected with poor health status, which also causes an increase in the risk of hip fracture [41].

The guidelines published by the Institute of Medicine (IOM) recommend that serum 25(OH)D levels $\geq 50 \mathrm{nmol} / \mathrm{L}$ ( $\geq 20 \mathrm{ng} / \mathrm{ml}$ ) can benefit skeletal health [12]. In this study, the dose-response meta-analysis showed a descending curve below the line of $\mathrm{RR}=1$, which was consistent with the results of the forest plot in Figure 2; however, no significant curvilinear association between serum $25(\mathrm{OH}) \mathrm{D}$ levels and the risk of hip fracture was found. Additionally, using the RR curve in Figure 3, we found that the curve descended before the level of $60 \mathrm{nmol} / \mathrm{L}$, then the curve trend became flat; therefore, when serum $25(\mathrm{OH}) \mathrm{D}$ levels are $<60 \mathrm{nmol} / \mathrm{L}$, increasing serum $25(\mathrm{OH}) \mathrm{D}$ levels may significantly decrease the risk of hip fracture, and after reaching $60 \mathrm{nmol} / \mathrm{L}$, increasing serum $25(\mathrm{OH}) \mathrm{D}$ levels will not decrease the risk of hip fracture. The transitional serum $25(\mathrm{OH}) \mathrm{D}$ level in this meta-analysis $(60 \mathrm{nmol} / \mathrm{L})$ was $10 \mathrm{nmol} / \mathrm{L}$ higher than that recommended by the Institute of Medicine (IOM) $(\geq 50$ $\mathrm{nmol} / \mathrm{L})$ [12].

\section{Strengths of this study}

The strength of this meta-analysis is that our quantitative assessment is based on prospective cohort studies, which can overcome the weaknesses of recall and selection bias in case-control studies and provide more data on hip fracture risk within the population. To the best of our knowledge, this is the first systematic review and meta-analysis of the relationship between serum $25(\mathrm{OH})$ $\mathrm{D}$ levels and the risk of hip fracture based on prospective cohort studies. Moreover, we performed subgroup analyses by gender, age, location, study design and followup term, and the results were consistent to the overall result. We also performed dose-response assessments of the relationship between serum $25(\mathrm{OH}) \mathrm{D}$ levels and the risk of hip fracture. Finally, all of the included studies had high quality assessment scores (7-9 stars, nine-star Newcastle-Ottawa scale) and long durations of follow-up, with a large population of 51239 participants totally.

\section{Limitations of this study}

There are still some limitations of our meta-analysis. Firstly, not all of the studies met the requirement of doseresponse meta-analysis; only four of included studies were pooled for dose-response meta-analysis. Secondly, There were some different $25(\mathrm{OH}) \mathrm{D}$ assays exist, in general, they can be grouped into 2 different categories: immune based and chromatography based [42]. According to the current views, the intra-assay variation may reach $0-10 \%$, while the inter-assay variation may reach $0-25 \%$ (at lower serum levels) [43, 44]. Therefore, the variation is existed, and can't be avoided, we should be kept in mind when following an individual patient over time [44]. Thirdly, some factors that vitamin D measurements in blood samples drawn from fracture patients in the acute phase may be influenced by the trauma and surgery itself-such as by inflammation [45] or hemodilution caused by fluid supply [46].

\section{CONCLUSIONS AND CLINICAL IMPLICATION}

Individuals with low levels of serum 25(OH)D have an increased risk of hip fracture, and this effect was evident when the serum $25(\mathrm{OH}) \mathrm{D}$ level was less than 60 $\mathrm{nmol} / \mathrm{L}$, and disappeared when the serum 25(OH)D level was more than $60 \mathrm{nmol} / \mathrm{L}$.

\section{MATERIALS AND METHODS}

The present study was completed according to the preferred reporting items for systematic review and metaanalyses (PRISMA) statement (Checklist S1).

\section{Search strategy}

We systematically searched PubMed and EMBASE on September 15, 2016 using the following keywords: 1) 25-hydroxyvitamin $\mathrm{D}, 25(\mathrm{OH}) \mathrm{D}$, or vitamin $\mathrm{D}$; 2) hip fractures or hip fracture; 3) cohort study, cohort studies, prospective study, prospective studies, or longitudinal study. We conducted the searches without language and publication year restrictions. In addition, we manually scanned the related articles and used the "related article" function for additional searches to avoid initial misses.

\section{Selection criteria}

The criteria for inclusion in this meta-analysis were as follows: (1) the study was designed as a prospective cohort study; (2) exposure of interest is $25(\mathrm{OH}) \mathrm{D}$; (3) primary outcome of interest is hip fracture; and (4) relative risk (RR) and the corresponding 95\% confidence interval 
(CI) were reported or could be calculated using the data reported. If the data were overlapped or duplicated by multiple publications, the study with the larger number of cases was included

And the criteria of exclusion were: (1) the retrospective study; (2) No data of $25(\mathrm{OH}) \mathrm{D}$ and hip fracture was described; (2) meeting abstract that couldn't found the full text; (4) the RR and 95\%CI were not reported or couldn't be calculated using the reported data.

Two authors (QBL and XG) independently scanned the potential studies to determine which studies were eligible. Disagreements were discussed first and resolved by a third independent author (AMW).

\section{Data extraction}

Three investigators (XL, QHX and ZXS) independently extracted data and the other author (YLC) cross-checked the data for consistency. Differences and disagreements were resolved by consensus. The data were recorded using a standard data extraction form, including the first author's last name, publication year, country where the study was performed, study period, sample size (cases and controls or cohort size), gender and age of participants, measure and range of exposure, variables adjusted for analysis, and RR estimates with corresponding $95 \% \mathrm{CI}$ for each category of $25(\mathrm{OH}) \mathrm{D}$. If there were more RRs for different potential confounders, we extracted the RRs that reflected the greatest degree of control for potential confounders. If necessary, we contacted the authors of the primary studies for additional information. The nine-star Newcastle-Ottawa scale was used to assess the study quality $[47,48]$.

\section{Statistical analysis}

First, RR estimates were combined using a fixedeffects model as a common measure of the relationship between serum 25(OD)D levels and the risk of hip fracture across studies. To obtain a more accurate result, we pooled the RRs and 95\%CIs of the lowest $v s$. the highest categories for synthesis to determine the risk of hip fracture with low $25(\mathrm{OH}) \mathrm{D}$ concentrations [49-51].

Second, we conducted a subgroup meta-analysis to examine the significance of the difference in RRs by different subgroups, including gender (male and female), age ( $\geq 65$ years and $\geq 42$ years), location (Europe and USA), study type (cohort study and case cohort study) and the duration of follow-up ( $<7$ years and $\geq 7$ years). And the covariates (year, age, follow-up term, study-type, gender and location) meta-regression was performed to observe the potential heterogeneity.

Third, to examine the association between $25(\mathrm{OH})$ $\mathrm{D}$ levels and the risk of hip fractures, a dose-response meta-analysis was fitted using 4 knots at the following percentiles of distribution: $5 \%, 35 \%, 65 \%$ and $95 \%$ of the distribution [52]. We used the random-effects model reported by Greenland and Longnecker [53] and Orsini et al [54] to conduct a dose-response meta-analysis of $25(\mathrm{OH}) \mathrm{D}$ levels. For consistency within the included studies, 25(OH)D concentrations are reported in "nmol/L". Concentrations reported in "ng/ml" by some studies were converted using a conversion factor $(1 \mathrm{ng} / \mathrm{ml}=2.5$ $\mathrm{nmol} / \mathrm{L})$.

Finally, statistical heterogeneity between studies was quantified by using Cochran's $\mathrm{Q}$ and the $\mathrm{I}^{2}$ statistic [55]. To investigate the influence of the individual data on the pooled results, we performed a sensitivity analysis to assess the influence of a single study on the pooled RR estimate by removing one study at a time. We also performed the Egger's asymmetry regression test to evaluate potential publication bias [56]. All statistical tests were performed using STATA software (Version 12.0; Stata Corp, College Station, Texas).

\section{Authors' contributions}

QBL, AMW, YLC contribute to the conception and design of the study, QBL, XG, XL, QHX, HZX, and ZXS contribute to analysis and interpretation of data, QBL and AMW contribute to drafting the article, All of authors revise it critically for important intellectual content, and to final approval of the version to be published.

\section{ACKNOWLEDGMENTS}

This work was funded by the National Natural Science Foundation of China (81501933, 81372014), Wenzhou Science and Technology Project (Y20160369), National Undergraduate Innovation and Entrepreneurship Training Program of China (201510343002), and Xinmiao talent plan of Zhejiang Province (2015R413005, 2016R413060). The funders had no role in the design, execution, or writing of the study.

\section{CONFLICTS OF INTEREST}

Qing-Bo Lv, Xiang Gao, Xiang Liu, Zhen-Xuan Shao, Qian-Hui Xu, Hua-Zi Xu, Yong-Long Chi, and AiMin $\mathrm{Wu}$ declare that they have no conflict of interest.

\section{REFERENCES}

1. Cummings SR, Melton LJ. Epidemiology and outcomes of osteoporotic fractures. Lancet. 2002; 359:1761-67.

2. Delmas PD. Treatment of postmenopausal osteoporosis. Lancet. 2002; 359:2018-26.

3. Lin X, Xiong D, Peng YQ, Sheng ZF, Wu XY, Wu XP, Wu F, Yuan LQ, Liao EY. Epidemiology and management of osteoporosis in the People's Republic of China: current perspectives. Clin Interv Aging. 2015; 10:1017-33. 
4. Cooper C, Campion G, Melton LJ 3rd. Hip fractures in the elderly: a world-wide projection. Osteoporos Int. 1992; 2:285-89.

5. Kannus P, Parkkari J, Sievänen H, Heinonen A, Vuori I, Järvinen M. Epidemiology of hip fractures. Bone. 1996 (Suppl); 18:57S-63S.

6. Xia WB, He SL, Xu L, Liu AM, Jiang Y, Li M, Wang O, Xing XP, Sun Y, Cummings SR. Rapidly increasing rates of hip fracture in Beijing, China. J Bone Miner Res. 2012; 27:125-29.

7. Cenzer IS, Tang V, Boscardin WJ, Smith AK, Ritchie C, Wallhagen MI, Espaldon R, Covinsky KE. One-Year Mortality After Hip Fracture: Development and Validation of a Prognostic Index. J Am Geriatr Soc. 2016; 64:1863-68.

8. Xu J, Song C, Song X, Zhang X, Li X. Carotenoids and risk of fracture: a meta-analysis of observational studies. Oncotarget. 2017; 8:2391-2399. doi: 10.18632/ oncotarget.13678.

9. Yang L, Lv X, Wei D, Yue F, Guo J, Zhang T. Metabolic syndrome and the risk of bone fractures: A Meta-analysis of prospective cohort studies. Bone. 2016; 84:52-56.

10. Lee DR, Lee J, Rota M, Lee J, Ahn HS, Park SM, Shin D. Coffee consumption and risk of fractures: a systematic review and dose-response meta-analysis. Bone. 2014; 63:20-28.

11. Starup-Linde J, Gregersen S, Vestergaard P. Associations with fracture in patients with diabetes: a nested case-control study. BMJ Open. 2016; 6:e009686.

12. Ross AC, Manson JE, Abrams SA, Aloia JF, Brannon PM, Clinton SK, Durazo-Arvizu RA, Gallagher JC, Gallo RL, Jones G, Kovacs CS, Mayne ST, Rosen CJ, Shapses SA. The 2011 report on dietary reference intakes for calcium and vitamin D from the Institute of Medicine: what clinicians need to know. J Clin Endocrinol Metab. 2011; 96:53-58.

13. Hansen KE, Johnson RE, Chambers KR, Johnson MG, Lemon CC, Vo TN, Marvdashti S. Treatment of Vitamin D Insufficiency in Postmenopausal Women: A Randomized Clinical Trial. JAMA Intern Med. 2015; 175:1612-21.

14. Bischoff-Ferrari HA, Giovannucci E, Willett WC, Dietrich T, Dawson-Hughes B. Estimation of optimal serum concentrations of 25-hydroxyvitamin D for multiple health outcomes. Am J Clin Nutr. 2006; 84:18-28.

15. Holick MF. Vitamin D deficiency. N Engl J Med. 2007; 357:266-81.

16. Fu Y, Hu Y, Qin Z, Zhao Y, Yang Z, Li Y, Liang G, Lv H, Hong H, Song Y, Wei Y, Yue H, Zheng W, et al. Association of serum 25-hydroxyvitamin D status with bone mineral density in 0-7 year old children. Oncotarget. 2016; 7:80811-19. doi: 10.18632/oncotarget.13097.

17. Steingrimsdottir L, Halldorsson TI, Siggeirsdottir K, Cotch MF, Einarsdottir BO, Eiriksdottir G, Sigurdsson S, Launer LJ, Harris TB, Gudnason V, Sigurdsson G. Hip fractures and bone mineral density in the elderly-importance of serum 25-hydroxyvitamin D. PLoS One. 2014; 9:e91122.

18. Looker AC, Mussolino ME. Serum 25-hydroxyvitamin $\mathrm{D}$ and hip fracture risk in older U.S. white adults. J Bone Miner Res. 2008; 23:143-50.

19. Barbour KE, Houston DK, Cummings SR, Boudreau R, Prasad T, Sheu Y, Bauer DC, Tooze JA, Kritchevsky SB, Tylavsky FA, Harris TB, Cauley JA, and Health ABC Study. Calciotropic hormones and the risk of hip and nonspine fractures in older adults: the Health ABC Study. J Bone Miner Res. 2012; 27:1177-85.

20. Cummings SR, Browner WS, Bauer D, Stone K, Ensrud K, Jamal S, Ettinger B, and Study of Osteoporotic Fractures Research Group. Endogenous hormones and the risk of hip and vertebral fractures among older women. N Engl J Med. 1998; 339:733-38.

21. Chan R, Chan CC, Woo J, Ohlsson C, Mellström D, Kwok $\mathrm{T}$, Leung PC. Serum 25-hydroxyvitamin D, bone mineral density, and non-vertebral fracture risk in communitydwelling older men: results from Mr. Os, Hong Kong. Arch Osteoporos. 2011; 6:21-30.

22. de Boer IH, Levin G, Robinson-Cohen C, Biggs ML, Hoofnagle AN, Siscovick DS, Kestenbaum B. Serum 25-hydroxyvitamin $\mathrm{D}$ concentration and risk for major clinical disease events in a community-based population of older adults: a cohort study. Ann Intern Med. 2012; 156:627-34.

23. Cauley JA, Parimi N, Ensrud KE, Bauer DC, Cawthon PM, Cummings SR, Hoffman AR, Shikany JM, Barrett-Connor E, Orwoll E, and Osteoporotic Fractures in Men (MrOS) Research Group. Serum 25-hydroxyvitamin D and the risk of hip and nonspine fractures in older men. J Bone Miner Res. 2010; 25:545-53.

24. Holvik K, Ahmed LA, Forsmo S, Gjesdal CG, Grimnes G, Samuelsen SO, Schei B, Blomhoff R, Tell GS, Meyer HE. Low serum levels of 25-hydroxyvitamin D predict hip fracture in the elderly: a NOREPOS study. J Clin Endocrinol Metab. 2013; 98:3341-50.

25. Robinson-Cohen C, Katz R, Hoofnagle AN, Cauley JA, Furberg CD, Robbins JA, Chen Z, Siscovick DS, de Boer $\mathrm{IH}$, Kestenbaum B. Mineral metabolism markers and the long-term risk of hip fracture: the cardiovascular health study. J Clin Endocrinol Metab. 2011; 96:2186-93.

26. Khaw KT, Luben R, Wareham N. Serum 25-hydroxyvitamin $\mathrm{D}$, mortality, and incident cardiovascular disease, respiratory disease, cancers, and fractures: a 13-y prospective population study. Am J Clin Nutr. 2014; 100:1361-70.

27. Cauley JA, Lacroix AZ, Wu L, Horwitz M, Danielson ME, Bauer DC, Lee JS, Jackson RD, Robbins JA, Wu C, Stanczyk FZ, LeBoff MS, Wactawski-Wende J, et al. Serum 25-hydroxyvitamin D concentrations and risk for hip fractures. Ann Intern Med. 2008; 149:242-50.

28. Melhus H, Snellman G, Gedeborg R, Byberg L, Berglund L, Mallmin H, Hellman P, Blomhoff R, Hagström E, Arnlöv J, Michaëlsson K. Plasma 25-hydroxyvitamin D levels and 
fracture risk in a community-based cohort of elderly men in Sweden. J Clin Endocrinol Metab. 2010; 95:2637-45.

29. Bolland MJ, Bacon CJ, Horne AM, Mason BH, Ames RW, Wang TK, Grey AB, Gamble GD, Reid IR. Vitamin D insufficiency and health outcomes over $5 \mathrm{y}$ in older women. Am J Clin Nutr. 2010; 91:82-89.

30. Buchebner D, McGuigan F, Gerdhem P, Malm J, Ridderstråle M, Åkesson K. Vitamin D insufficiency over 5 years is associated with increased fracture risk-an observational cohort study of elderly women. Osteoporos Int. 2014; 25:2767-75.

31. Takiar R, Lutsey PL, Zhao D, Guallar E, Schneider AL, Grams ME, Appel LJ, Selvin E, Michos ED. The associations of 25-hydroxyvitamin D levels, vitamin D binding protein gene polymorphisms, and race with risk of incident fracture-related hospitalization: twenty-year follow-up in a bi-ethnic cohort (the ARIC Study). Bone. 2015; 78:94-101.

32. General S. Bone health and osteoporosis: a report of the surgeon general. Rockville (MD): US Department of Health and Human Services, Office of the Surgeon General; 2004.

33. Roddam AW, Neale R, Appleby P, Allen NE, Tipper S, Key TJ. Association between plasma 25-hydroxyvitamin D levels and fracture risk: the EPIC-Oxford study. Am J Epidemiol. 2007; 166:1327-36.

34. Lai JK, Lucas RM, Clements MS, Roddam AW, Banks E. Hip fracture risk in relation to vitamin D supplementation and serum 25-hydroxyvitamin D levels: a systematic review and meta-analysis of randomised controlled trials and observational studies. BMC Public Health. 2010; 10:331.

35. Lips P. Vitamin D deficiency and secondary hyperparathyroidism in the elderly: consequences for bone loss and fractures and therapeutic implications. Endocr Rev. 2001; 22:477-501.

36. Gerdhem P, Ringsberg KA, Obrant KJ, Akesson K. Association between 25-hydroxy vitamin D levels, physical activity, muscle strength and fractures in the prospective population-based OPRA Study of Elderly Women. Osteoporos Int. 2005; 16:1425-31.

37. Muir SW, Montero-Odasso M. Effect of vitamin D supplementation on muscle strength, gait and balance in older adults: a systematic review and meta-analysis. J Am Geriatr Soc. 2011; 59:2291-300.

38. Dawson-Hughes B, Harris SS, Krall EA, Dallal GE. Effect of calcium and vitamin D supplementation on bone density in men and women 65 years of age or older. N Engl J Med. 1997; 337:670-76.

39. Kalyani RR, Stein B, Valiyil R, Manno R, Maynard JW, Crews DC. Vitamin D treatment for the prevention of falls in older adults: systematic review and meta-analysis. J Am Geriatr Soc. 2010; 58:1299-310.

40. Bischoff HA, Stähelin HB, Dick W, Akos R, Knecht M, Salis C, Nebiker M, Theiler R, Pfeifer M, Begerow B, Lew RA, Conzelmann M. Effects of vitamin D and calcium supplementation on falls: a randomized controlled trial. J Bone Miner Res. 2003; 18:343-51.

41. Semba RD, Garrett E, Johnson BA, Guralnik JM, Fried LP. Vitamin D deficiency among older women with and without disability. Am J Clin Nutr. 2000; 72:1529-34.

42. Binkley N, Wiebe D. Clinical controversies in vitamin D: $25(\mathrm{OH}) \mathrm{D}$ measurement, target concentration, and supplementation. J Clin Densitom. 2013; 16:402-08.

43. Ontario HQ, and Health Quality Ontario. Clinical utility of vitamin d testing: an evidence-based analysis. Ont Health Technol Assess Ser. 2010; 10:1-93.

44. Lips P. Relative value of $25(\mathrm{OH}) \mathrm{D}$ and $1,25(\mathrm{OH}) 2 \mathrm{D}$ measurements. J Bone Miner Res. 2007; 22:1668-71.

45. Cannell JJ, Grant WB, Holick MF. Vitamin D and inflammation. Dermatoendocrinol. 2015; 6:e983401.

46. Krishnan A, Ochola J, Mundy J, Jones M, Kruger P, Duncan E, Venkatesh B. Acute fluid shifts influence the assessment of serum vitamin D status in critically ill patients. Crit Care. 2010; 14:R216.

47. Stang A. Critical evaluation of the Newcastle-Ottawa scale for the assessment of the quality of nonrandomized studies in meta-analyses. Eur J Epidemiol. 2010; 25:603-05.

48. Zeng X, Zhang Y, Kwong JS, Zhang C, Li S, Sun F, Niu $\mathrm{Y}, \mathrm{Du} \mathrm{L}$. The methodological quality assessment tools for preclinical and clinical studies, systematic review and meta-analysis, and clinical practice guideline: a systematic review. J Evid Based Med. 2015; 8:2-10.

49. Larsson SC, Orsini N, Wolk A. Vitamin B6 and risk of colorectal cancer: a meta-analysis of prospective studies. JAMA. 2010; 303:1077-83.

50. Wu AM, Huang CQ, Lin ZK, Tian NF, Ni WF, Wang XY, $\mathrm{Xu}$ HZ, Chi YL. The relationship between vitamin A and risk of fracture: meta-analysis of prospective studies. J Bone Miner Res. 2014; 29:2032-39.

51. Ma X, Tang WG, Yang Y, Zhang QL, Zheng JL, Xiang YB. Association between whole grain intake and all-cause mortality: a meta-analysis of cohort studies. Oncotarget. 2016; 7:61996-2005. doi: 10.18632/oncotarget.11491.

52. Harrell FE Jr, Lee KL, Pollock BG. Regression models in clinical studies: determining relationships between predictors and response. J Natl Cancer Inst. 1988; 80:1198202.

53. Greenland S, Longnecker MP. Methods for trend estimation from summarized dose-response data, with applications to meta-analysis. Am J Epidemiol. 1992; 135:1301-09.

54. Orsini N, Bellocco R, Greenland S. Generalized least squares for trend estimation of summarized dose-response data. Stata J. 2006; 6:40.

55. Higgins JP, Thompson SG. Quantifying heterogeneity in a meta-analysis. Stat Med. 2002; 21:1539-58.

56. Egger M, Davey Smith G, Schneider M, Minder C. Bias in meta-analysis detected by a simple, graphical test. BMJ. 1997; 315:629-34. 